\title{
Not by P Alone: A Virtuous Economy
}

\author{
DEIRDRE N. MCCLOSKEY
}

Department of Economics, University of Illinois at Chicago, USA and Academia Vitae, Deventer, The Netherlands

AbSTRACT Samuelsonian (mainstream) economics cannot even think of stepping beyond its Max U, prudence-only model. But if we are going to have an economics that works and that matters, as economists like Sen and Akerlof and Hirschman have been saying, we need to admit that people do not live by prudence alone. They love and hope, they are just or unjust, they are temperate and courageous, faithless or faithful. Recognizing such virtues and vices is not a betrayal of economics. It is a fulfillment of the political economy of Adam Smith.

\section{Getting from Sen to the Seven Virtues}

Let me start where many of you will, with Amartya Sen. Sen (1987, p. 41) distinguishes between 'well-being,' which is the utilitarian notion of people as pots into which pleasure is dumped, and 'agency,' 'the ability to form goals, commitments, values, etc.' 'Goals, commitments, and values,' whatever exactly they are - Sen does not go into them in detail, perhaps in deference to the squeamishness about such transcendent matters in a non-religious culture - are certainly well beyond mere price, profit, property. Such $P$ variables, as I call them, are means, not ends. But certainly agency is to be understood, far beyond means, as the ability and the desire to form goals, as, say, a child cannot in safety. Having the means is important, as any economist would argue, and as Sen and Nussbaum and even Chicago-School McCloskey certainly do. But segregating the ends or goals or the purposes of life into a ghetto of sheer unanalyzed taste, as economists led by Paul Samuelson have rigorously done since the 1930s, has been a scientific mistake. That's the main point of the uneasiness expressed in Sen and Hirschman and Akerlof, and here.

One can distinguish the prudence, price, profit, the Profane, ' $P$ variables' and the agency solidarity, society, speech, the Sacred, ' $S$ variables.' ${ }^{1}$ As the historian of religion Mircea Eliade (1959, p. 14) put it, 'sacred and profane are two modes of being in the world.' But it helps to insert between the profane and the sacred some $O$ variables, other regarding concerns for justice, and the secular parts of love, and

Correspondence Address: Deirdre N. McCloskey Department of Economics, University of Illinois at Chicago, Chicago, IL 60607, USA and Academia Vitae, Deventer, The Netherlands. Email: Deirdre@uic.edu

${ }^{1}$ The full story appears in McCloskey (2006), from which this essay is adapted. 
the self-sacrificing parts of courage. These are part of what Sen calls goals, commitments, and values. But they are incomplete without the third level, $S$ variables, consisting of the transcendents: hope, faith, and the transcendent part of love. The $S$ variables give point to exercises of $O$ and $P$ variables.

The seven virtues here specified - prudence, temperance, courage, justice, love, faith, and hope - derive from an old European vocabulary, with parallels in Confucian and Buddhist and other ethical thought. Their age does not make them inferior to recent coinages. I'm recommending that to get beyond mere uneasiness about, say, Gary Becker and $P$-only variables we need a richer vocabulary than agency or identity or voice.

My point here is that humans, of course, live through $P$ and $O$ and $S$, all three. That's perfectly obvious. The $P$ variables are beloved of economics, the $O$ are beloved of sociology, and the $S$ variables are beloved of theology. But we need usually to keep all three in mind, or else we are going to get into scientific trouble. For example, if we insist that well-being is all there is, that humans just are pots for pleasure-dumping, that any economic analysis by definition must be the exercise in maximizing utility that Samuelson taught so well, then we forget the influence of a mother's love for her child, beyond price, or a businessperson's commitment to a faithful identity as a good person, beyond profit. 'The rudimentary hard-headedness attributed to them by modern economics,' as Sen $(1987$, p. 2) puts it, which is the virtue of prudence, is the only virtue in the economists' world. But neglecting $O$ and especially $S$ is a wider rhetorical problem than academic economics. It affects the performance of the economy. Michael Novak (1996, p. 4) observes that in the modern world 'a strictly economic, business language has grown up without including within itself the moral, religious, even humane language appropriate to its own activities.' That's the problem. We have been corrupted by our $P$-only talk.

Laurel Ulrich (1990, p. 203), in her biography of Martha Ballard, wife of a miller/surveyor, mother of nine children, but especially a midwife delivering over 800 babies in the Maine of the Early National period, reflects on why Martha did it. 'What took Martha Ballard out of bed in the cold of night? Why was she willing to risk frozen feet and broken bones to practice her trade? Certainly midwifery paid well.' There's the prudence, supplemented by temperance and self-regarding courage to cross river ice to get to her deliveries, and she had no saintly abnegation about it: "Martha cared about her "rewards," and she kept her midwifery accounts carefully.' Yet she was not a creature of $P$ only. Ballard's specialty brought together the gentle and giving side of her nature [thus $O$ love] with her capacity for risk and her need for autonomy [thus $O$ courage and $S$ hope]. And faith mattered. Her diary is full of conventional praises to God, and often more than conventional. 'She interpreted her work, as all her life, in religious terms.' Interpretation involves goals, commitments, values. 'But even more [midwifery] ... was an inner calling, an assertion of being.' $P$ and $O$ and $S$ all work in bourgeois and other lives.

\section{Why People Do Things}

A master-word in Dutch culture is zuinig, meaning thrifty, frugal, economical. Nothing peculiar about that, you might say - all cultures have to deal prudently 
with the fact of scarcity - until you note how very far the Dutch take it in practice. An American would be ashamed to go to the lengths of zuinig behavior that are seen as compulsory scripts in Holland.

The candle-culture of the country is a nice offset to a wet, dreary climate. But a Dutch housewife, regardless of income, would be ashamed to light candles unless it was after sunset. Her shame is a cultural memory of a time in which saving candles mattered. Classrooms in Dutch and other European universities depend on natural light unless the sun has gone down. No waste of lighting at midday, whether or not the atmosphere is gloomy and the blackboard indiscernible, as it often is in the Department of Philosophy at Erasmus University. A well-to-do Hollander will subject himself to an extra hour of shopping in order to get the hoped-for bargains at the periodic vegetable market in the town square, muttering to himself one of the scores of Dutch proverbs exalting thrift. Zuinigheid met vlijt bouwt huizen als kastelen - literally, 'Thriftiness with diligence builds houses like castles'; freely, 'Take care of the pence, and the pounds will take care of themselves.'

The kaasschaaf, the cheese-parer, for slicing very thin slices off the block of cheese is picked up by Americans as a novelty as they leave Schiphol airport. But they don't use it once they get home. Instead they go on as before cutting off whole big chunks to eat that would scandalize a Dutch housewife. In truth, hard cheese does taste better when pared, so the paring could be explained as rational in a cheese-eating nation. But there are less easily evaded cases. All Dutch kitchens are supplied with a utensil for scraping out the last little bit of yoghurt or spaghetti sauce from a jar. It is called by the Dutch a flessenkrabber, a bottle-scraper, consisting of a tiny rounded rubber edge attached to a foot-long plastic handle. Dutch people cannot believe that other nations don't have it - well, except for New Englanders of an earlier generation, among perhaps a few others, which makes again the point of its strangeness in a rich world. Even poor Dutch people could get along without the fraction-of-a-cent's worth of sauce sacrificed if the unscraped bottle was thrown into the trash - no, I'm sorry, into the recycling bin. And the Netherlands has been one of the richest countries in the world for centuries.

People scrape not out of prudence only, not for $P$ values, but because that is what a Dutch person should do, $S$-style, like scrubbing the front stoop, or skating the Eleven-Town Tour when the canals in Friesland ice up. It is a 'sacrifice,' literally 'making sacred,' the $S$-holy deed of paying homage to one's Dutchness. And that is what the Dutch say when you laugh at their flessenkrabbers. They retort that food is God's gift, and it is therefore sinful to waste it. Or in a more socialist vein they say that to waste it is to insult the labor that went into producing it. Or, such theologies aside, they declare that they were raised anyway as Dutch people to do so. Their identity is sacred.

Americans believe, as Huey Long said, 'Every man a king.' Kings are not supposed to tolerate dimly-lit rooms before dark or save tiny dollops of spaghetti sauce or, as the Dutch also routinely do, reuse teabags. Those would be absurd, ignoble things for a king. An American CEO feels that he should, in honor of his kingly estate, buy an expensive lunch. He leaves a big tip for the same reason. 
Tipping indeed is an easy-to-observe outcome of a sacred decision, like going to church. Some nations that tip in restaurants are the United States (with the highest percentage of the bill internationally: $16.7 \%$ by survey), Canada, the UK, Mexico, Egypt. Some that don't tip much or at all are the Netherlands, Denmark, Sweden, Finland, Estonia, Japan, Australia, and New Zealand. ${ }^{2}$ France and Italy occupy a non-sacred middle ground of service compris. Researchers on tipping agree that one cannot devise an explanation of tipping on the basis of simple, first-order prudence. Either you honor your Australian values of egalitarianism by sitting in the front seat with the cab driver and not giving him a tip; or you show your American desire to be liked, yet show also your comfortableness with power differentials, by tipping generously in the United States. No simply prudent purpose is served, unless you think the anonymous cab driver in New York whom you stiff may take out a gun and shoot you.

Robert Frank (1988, p. 18) argues persuasively that 'the decision to tip in a distant city is about the kinds of character traits one wishes to cultivate.' $\mathrm{He}$ then goes to some lengths - some of it persuasive - to tell a story of $P$-motivated decisions to become a certain character. Frank, like me, is an economist, sworn to find $P$-only reasons every chance he gets. That, and the secret handshake. He is trying to reduce $S$ or $O$ to a sort of elevated $P$. But I think he would agree that many if not all variations in $S$-behavior or $O$-behavior are best explained as just $S$ or $O$, not as stalking horses for various sorts of hidden prudence.

The economist could reply that bargaining over a little olive oil or scraping a little spaghetti sauce or even tipping at restaurants are minor matters. The economic historian Eric Jones calls it the assumption of 'cultural nullity.' He observes that the non-economist's recitation of instances of irrational attachment to zuinigheid 'is followed by a heroic leap to the assumption that because certain classes of social behavior visibly differ from place to place, they must be significant, even dominant, influences on how people behave with respect to larger matters' (Jones 2006, p. 5). In larger matters, the economist would say - Jones himself reserves judgment - that people are governed by $P$ alone. Max $U$ suffices. Jones (2006, p. 22) quotes as an extreme example the views of an admirable economist, the late Julian Simon, on fertility: 'culture and values do not have independent lives ... [but] serve as intermediate variables between economic conditions and fertility.' I think not.

\section{Can Markets Generate the Virtues?}

In her wide-ranging survey of the limits of $P$-only social thinking, Irene van Staveren $(1999,2001)$ looks at it from the eighth floor, so to speak. In the manner encouraged by Arjo Klamer, she distinguishes three spheres. They are the government, whose virtue is justice; the market, whose virtue is prudence or freedom, what I would call courage; and the home, whose virtue is love. The

\footnotetext{
${ }^{2}$ Lynn \& Lynn (2004, Table 1). It is not entirely clear how to interpret blanks in the table. I think they mean 'no tipping beyond compulsory additions to the bill' (as in Italy); also, I am puzzled by the 15\% for France.
} 
Greek words are agora, polis, and oikos. The talk of 'spheres,' by the way, is especially natural in Dutch, from the long political tradition in the Netherlands of so-called 'pillars' (zuilen) of autonomous communities, Dutch Reform, Catholic, socialist, Jewish, and now Moslem.

The key to van Staveren's thinking is a brilliant table in which she lays out the three spheres and their modes of ethical values, feelings, reasoning, and action. She criticizes an early version of my argument for mixing up the columns and, in particular, for including in a bourgeois column

\begin{abstract}
the virtue of 'affection' that Hume found to be furthered outside the market, ... the virtue of 'trust' that Mill, Polanyi, and Hirschman have located in caring relationships in the home, in the community, or among consumers of employees but not in a market transaction, ... the virtue of 'respect' that Mill and Perkins Gilman found to be supported outside the market, ... and the virtue of 'responsibility' that Hayek and Friedman recognized as belonging outside the market but at the same time as a precondition for market transactions to happen. (van Staveren, 1999, p. 83)
\end{abstract}

I agree that I was once unclear about just how such virtues arise in market societies. I still am, I suppose, although from reading van Staveren and Sen and Nussbaum and others I believe I'm a little less so now, and will be exploring the issue in the second volume of my quartet on bourgeois virtues, Bourgeois Towns: How Capitalism Became Ethical 1600-1776. Van Staveren and I agree that such values are necessary for markets to work, and that a society without a polis or an oikos, a domain of justice or of care, will be deficient in them, nightmarish. A virtue such as trust 'is a value that markets need.'

But we disagree about whether markets can 'generate' trust, or whether trust can only be 'furthered and nurtured outside the market in what [van Staveren has] called the care economy. ${ }^{3}$ Van Staveren thinks of the market here as operating overwhelmingly 'through calculation, interest, and exchange.' Admittedly, such a mechanical and $P$-only thing could not 'generate' trust. Without some love or solidarity, like a starter in sour-dough bread, no one would trust anybody. Feminist economist Nancy Folbre (2001, p. vii) says, and I agree, that 'the invisible hand of [anonymous, mechanical] markets depends on the invisible heart of care. Markets cannot function effectively outside the framework of families and communities built on values of love, obligation, and reciprocity.' The philosopher Lester Hunt (1997, p. 211) makes a similar point, based on a similar dichotomy: the power of commerce over the formation of character 'is checked by that of other sectors, including especially the radically contrasting institution of the gift.'

Granted. But are $P$-only calculations, interest, and exchange what markets overwhelmingly consist of? I think not, although again (in a spirit of making mutual progress in thinking about such matters instead of just screaming at each other) I readily admit that the ill-named 'mainstream' economics thinks so. I think, and believe van Staveren and Folbre and Hunt would agree, that actual

\footnotetext{
${ }^{3}$ van Staveren (1999, p. 88). A little surprisingly, she is summarizing and agreeing with Oliver Williamson here. What is surprising is that a Samuelsonian economist would be making such a point. But he is.
} 
markets are often infused with $O$ and $S$ values. Of course, if you define markets as not generating on their own some courage, love, justice, hope, and so forth, then you can after a few paragraphs triumphantly conclude, as though it were an empirical finding, that markets do not generate courage, love, justice, hope, and so forth. Something like this has been going on since the 1940s in talk about the economy. In some circles it has gone on longer. The very word 'capitalism' was defined early in its troubled history as solely the restless stirring for gain. This absolute desire for enrichment, this passionate hunt for value (as it is actually put in the German of Marx, a P-only theorist, in Chapter 4 of Das Kapital; the English, although approved by Engels, is as usual a bad translation), draws on an anti-commercial theme originating in Aristotle. That settles it, before looking at the evidence, right?

No it doesn't. There's no evidence, actually, that greed or miserliness or selfinterest or $P$ behavior was new in the 16th or the 19th or any other century. Auri sacra fames, 'for gold the infamous hunger,' is from The Aeneid, Book III, line 57, not from Benjamin Franklin or Advertising Age. The propensity to truck and barter is human nature. Commerce is not some evil product of recent manufacture. Commercial behavior is one of the world's oldest professions. We have documentation of it from the earliest cuneiform writing, in clay business letters from Kish or Ashur offering compliments to your lovely wife and making a deal for copper from Anatolia or lapis lazuli from Afghanistan. Bad and good behavior in prudently buying low and selling high can be found anywhere, any time.

My friends on the left (and often my friends on the right, too) sometimes fail to grasp that actual market societies are at their center cooperative, not competitive. It is the great theme of Austrian economics. The Austrians gesture (perhaps not quite strongly enough) towards language, for example, and creativity, emphasizing the social dance involved. Mainstream economics, which I prefer to call 'Samuelsonian' in honor of its chief formalizer, on the contrary leaves out language and creativity and socialization in favor of routine calculation and stony-hearted 'individualism.' My left-leaning friends and many of my right-leaning friends speak of markets in the abstract in such a Samuelsonian definition. The abstraction of maximizing utility and atomistic competition has great merits, I would be the first to say (and have said, at length). But of course if your model assumes at the outset that people are merely non-language-using and a-cultural pleasure pots then you are not going to find much room for cooperation, trust, language, $S$ and $O$.

Bourgeois life, from the woman selling fans on the streets of Jakarta to Warren Buffett in 2006 giving $85 \%$ of his wealth to charity, is largely a matter of cooperation, not competition. A businessperson supplying to a market must cooperate on all sides - with her suppliers, with her employees (if any), and above all with her customers. It is the aristocrat, or the intellectual imitator of the aristocrat (which describes a good many of my beloved anti-market friends on left and right), who thinks of life as a game, a competition. The sneering aristocrat and the screaming intellectual do not need to cooperate with anyone. She takes, or begs, or steals, or demands as a right, what she wants, shouting her ideology at top volume. No deals. No relationships. No $O$ or $S$.

The philosopher Jennifer Jackson (1996, p. 80), for example (not an example of screaming, I hasten to add!), asks from the left how a capitalist life can be 
reconciled with moral virtues. The two temptations to vice in such a life, she supposes, are the encouragement of intemperance in consumption and the 'avid competitiveness' of the businessperson, 'the seeming unremitting need to be doing others down.' Her view is pretty common. But one would like to know the society of men or women that did not exhibit intemperance in consumption. I know that there is a widespread belief among intellectuals that many societies do not indulge in consumerism, and that modern society has been terribly corrupted by being so rich. But the belief seems to be mistaken. Within the limits imposed by the low or the high productivity of their economies, every human society from the Inuit of Greenland to the San of the Kalahari consumes everything it makes. Consumerism, though not entirely without content, I admit, is for the most part a modern myth of the intellectuals, with roots in the aristocratic/Christian disdain for the merchant. In 1985, Daniel Horowitz argued that the American clerisy had been, since the 1920s, in the grip of a 'modern moralism' about spending. The traditional moralism of the 19th century looked with alarm from the middle class down onto the workers and immigrants drinking beer and obeying Irish priests and in other ways showing their 'loss of virtue.' Traditional moralists like the US Commissioner of Labor, Carroll D. Wright, "had no basic reservations about the justice and efficacy of the economic system - their questions had to do with the values of workers and immigrants, not the value of capitalism' (Horowitz, 1985, pp. 166-167). The goods-producing miracle of capitalist cooperation provides big incomes, which, of course, result in big consumption. That's all there is to it. There is no macro-economic support for the economic system, as modern intellectuals since Hobson and Veblen have imagined, and as the austere side of Christian thought has long believed, in buy, buy, buy (McCloskey, 2004).

And one would like to know the society of men, capitalist or not, that did not exhibit an unremitting need to do others down. The play of competitiveness in the souls of modern businessmen does not seem to be essentially bourgeois. It reflects the jousting values of an aristocracy, or more accurately a neo-pseudo-aristocracy, and to the male roles governed in fantasy by them. Capitalism in modern times has been the greatest triumph of 'feminine' cooperation ever. It is called 'the division of labor.' So said the blessed Adam Smith, of whom van Staveren and I think so much.

Anyway, as Sen $(2000$, pp. 6, 112) puts it, 'the freedom to exchange words, or goods, or gifts does not need defensive justification in terms of their favorable but distant effects; they are part of the way human beings in society live.... We have good reasons to buy and sell, to exchange, and to seek lives that can flourish on the basis of transactions.' He instances the access of women to employment and credit in many third world countries that markets provide (Sen, 2000, pp. 115, 201). Capitalism-skeptics do not sufficiently acknowledge that market societies like 17th-century Holland provided voluntarily for universities and churches and opera houses, and invented the social safety net. As Sen (2000, p. 40) points out, 'the contribution of economic growth has to be judged not merely by the increase in private incomes, but also by the expansion of social services (including, in many cases, social safety nets) that economic growth may make possible.' The Church's charity, the model for the left's theory of a social gospel, had until then gone mainly to keep abbots supplied with the better wines. 
'The virtues nowadays thought of [as] especially worthy to be called moral virtues,' writes the philosopher Philippa Foot (2001, p. 17), 'are often contrasted with prudence.' But she shows this to be wrong. 'A reasonable modicum of selfinterest' is also an 'Aristotelian [necessity] for human beings.' She did not say 'the restless never-ending process of profit-making alone ..., this boundless greed after riches.' No serious ethical thinker believes that greed is good. She said 'a reasonable modicum of self-interest.'

It is not surprising to find women criticizing a separation of spheres that makes prudence with self-regarding courage and a bit of temperance into a masculine realm of action and the rest of the virtues into a cloistered realm of Virtue. The theologian Ellen Charry (2004, p. 21) notes that happiness has come to mean 'prudent utility,' what she calls 'a state of mild euphoria,' that pot into which ice cream is dumped. The modern supporters of such a view, such as Peter Singer or Shalom Asch, "would say that the "things other than happiness" "are indeed more important, because 'happiness, having been privatized, is thought to be self-serving.'

This attitude is socially disastrous, because on its terms there is no reason for people to want to contribute to the common good, since they assume that it will not make them happy.... Seeking happiness, which ancient philosophy recognized to be a universal and proper desire, now opposes being good. Concern for the loss of civility, the triumph of 'autonomous individualism' so bemoaned in recent sociology - as in the writings of Robert Bellah - is partly the result of an assumed enmity between goodness and happiness. (Charry, 2004, p. 21)

The most simpleminded, but very widely adopted, definition of 'ethical' is altruistic. These are $O$ values. The trouble is that a flourishing life needs additionally a whiff of the transcendent, a reason for being just or generous. It needs the goodness Charry speaks of, to be sure, attending to other people, O; but also the self and the transcendent. $P$ and $O$ and $S$.

Consider an entirely altruistic person, with $O$-only motivation, a 'moral saint,' as the philosopher Susan Wolf puts it. 'If the moral saint, is devoting all his time to feeding the hungry... then necessarily he is not reading Victorian novels, playing the oboe, or improving his backhand.... A life in which none of these possible aspects of character is developed may seem a life strangely barren' (Wolf, 1982, p. 81). But this exclusively public, social, altruistic, $O$-only definition of 'virtue' or 'morality' introduces a flaw into her case. In the style of many Anglophone philosophers she leaves out privately self-interested prudence as a virtue, and leaves out as well the transcendent virtues that would give point to playing the oboe or even improving ones backhand.

And so she lets her moral saints behave badly towards themselves, viewed both selfishly and from a proper transcendent respect for oneself as a human. This is not good. And indeed showing its badness is Wolf's point, by a reductio ad absurdum. It's the Jewish-mother version of goodness: 'Oh, don't bother to replace the bulb. I'll just sit here in the dark.' But the mother, after all, is God's creature, too (you can substitute a secular transcendent here if you wish), and benevolence therefore should include a just benevolence towards herself. Being 
wholly altruistic, $O$-only, and disregarding the claims of that person also in the room called Self, about whose needs the very Self is ordinarily best informed, and whose higher value the Self has a good chance of acknowledging, is making the same mistake as being wholly selfish, disregarding the claims of that person called Other. In both cases the mistake is to ignore someone and the transcendent goals, commitments, values that make behavior worthwhile.

The modern inclination to demoralize prudence, to set it apart from ethics as though prudence were itself not a virtue, is not simply stupid (though it has had some bad outcomes). Some wise philosophers like Michael Oakeshott have erected systems on the distinction between prudential (or enterprise) associations such as business firms on the one hand and moral associations on the other such as families. I am saying that in this matter some wise philosophers like Oakeshott have been mistaken. It may be that such a distinction is the typically modern ethical mistake, the mistaken assumption that homely Gemeinschaft is the exclusive site of virtue and that businesslike Gesellschaft is an ethical nullity. It is certainly Machiavelli's and Hobbes' and Tönnies' mistake. I say: let's stop making it, on the left and right.

Consider the last moderately complicated purchase you made - that remodeled kitchen, or a new car. It was a cooperation, built on trust. Where each quantum of trust originates is a deeper question of social psychology than any of us economists or philosophers is equipped to handle. I admit that some of the cooperation comes from habits developed in families, say. But even markets have trust, fairness, symbols built into them, and I would say, 'generated' in them. The van Staverenesque columns do mix.

In the end I think the School of Klamer would acknowledge this. Their purpose, like mine, is to overturn the $P$-only orthodoxy of mainstream, especially American, conservative economics. Thus, the Dutch learning.

\section{Actual Business Depends on Virtues and Vices}

But likewise in conservative America? $S$ is bigger there than the official $P$-only theories would allow. The economy is embedded in society, and psychology or 'sychology' to preserve the $S$. The tough-guy American style of making decisions about the Big Dig in Boston or about the Second Iraq War is a sacred thing, a matter of unexamined $S$ shrouded in cost-benefit ceremonies claiming $P$. Often enough it's a matter of the masculine pride of the quarterback in charge. It's an enactment of the simplicities of the American 'redemptive self,' as Dan McAdams puts it, Jimmy Stewart filibustering the Senate in Mr. Smith Goes to Washington, or George W. Bush in his 40s accepting Jesus as his personal savior. Why else would the Bostonians decide to bury a highway? Why else would the second Bush administration fib about the reasons for the Second Iraq War?

A woman friend of mine, once a specialist in billion-dollar bank loans, told me that the merger of Bank One of Chicago in 2004 with Morgan Chase of New York was in good part an ego-trip for the male CEOs involved - that, and also a prudent plan to pick up the gains left on the street by the irrationalities of Illinois banking law. Another woman friend, a big-time accountant in New York, told me that [male] egos as much as loopholes in the American tax 
code determine the way offshore business schemes have developed. John Maynard Keynes called the ego trips 'animal spirits'. Peter Dougherty (2002, p. 83) offers the phrase 'hormonal capitalism.' Keynes did not mean that all investment is random. He meant merely that the systematic part of the economist's explanation, the part that depends on close calculations of interest rates and expected returns, is only a part. It's a $P$ in an equation in which $S$ and $O$ also figure.

The claimed $P$-only rationality of modern life, celebrated and criticized and worried over by Max Weber, has been exaggerated. Weber (1958) thought (in 1905) that decisions were really made by calculation, that bureaucracy was really depersonalized, that corporations were really run along military lines, in an iron cage of rationality. A century after Weber - as many social scientists assume - bureaucratic and corporate decision-making must be all the more rational and $P$-dominated, yes? No. Someone who thinks that a business corporation is run like an army at war has never been in a corporation in business or for that matter in an army at war.

The myth of modern rationality starts early. D'Alembert's Encyclopédie of 1751, Bentham's Introduction to the Principles of Morals and Legislation of 1789, and Comte's Système de Politique Positive of 1851 are characteristic expressions. Ernest Renan, professor of Hebrew at the Collège de France from 1862 on, and most famous for his claim that Jesus was a good fellow if a trifle primitive and oriental, declared that 'we must make a marked distinction between societies like our own, where everything takes place in the full light of reflection, and simple and credulous communities,' such as those that Jesus preached in (Renan, 1863, Ch 15). After the events of the 20th century in Europe, which exhibited anything but the full light of reflection, one is amazed by such brisk rationalism.

The Danish professor of planning Bent Flyvbjerg and his colleagues have studied the rational cost estimates of 258 big transportation projects worldwide over the period 1927-1998, averaging \$350 million each in final cost. Road projects at their completion saw cost overruns of 20\% (in constant 1995 prices), bridges and tunnels 34\%, and railways 45\%. ${ }^{4}$ The Big Dig 1982-2004, at $\$ 14,600$ million, came in at $500 \%$ of its original estimate - all right, only two or three hundred percent allowing for inflation and new features.

This is not evidence that the politicians and engineers involved were irrational, personally speaking. It is merely evidence that collective decisions with other people's money are not governed by the same calculations as are personal expenditures. That and what economists call the 'winner's curse' in a bidding war: in a world of bridge-building, in which no one quite knows what the correct bid is, the company with the misfortune this time to guess low wins the bidding, and is regularly therefore stuck with cost overruns.

And we all know how far from being governed entirely by rational prudence even our personal expenditures are, with our own hard-earned money. Even without the winner's curse in bidding for a house or an antique - that is, even with fixed and known prices - we buy things that in the end do not prove to

\footnotetext{
${ }^{4}$ Flyvbjerg et al. (2003). I thank Jens Jorgensen for telling me about Flyvbjerg's work.
} 
have been worth it. Only if we knew exactly what personal valuation to put on that new fur coat would we avoid what could be called the consumer's curse. Since, contrary to the simplest $P$-only models of economic behavior, we do not know, we make mistakes. Look at automotive expenditures, to take a big and importantly $S$ - and $O$-driven part of consumption. No one who buys a new car, incurring the thousands of dollars of depreciation from the ten seconds it takes to drive the new car off the dealer's lot, is making his decision under the full light of reflection, 'just transportation.' Or look at your closet, jammed with consuming mistakes.

Flyvbjerg remarks in an editorial piece in Engineering News-Record that 'the entire structure of incentives is geared towards underestimating costs and overestimating benefits. When a project goes forward a lot of people profit. ${ }^{5}$ When I myself in the 1960s worked as a transportation economist we would laugh at the cost-benefit studies provided by major engineering firms to justify projects in developing countries. The benefits were double-counted and treble-counted, big elements of the costs ignored, and dubious social benefits were added in, until the government or the World Bank was satisfied. Forget about the Winner's Curse; this was the Winner's Con. But the entry of economists into the business has not much improved the situation, even in countries accustomed to transparency and ethical uprightness.

It is well known in Denmark itself that the Great Belt, connecting the Copenhagen island to the mainland, completed in 1998 at a cost of $\$ 4.3$ billion, was irrational. A tunnel alone would have been cheaper, since the distance was great. But the politicians wanted a beautiful bridge, and they were not paying for it, so they got it. The payoff period for the loans is said, even in official publications, to be as long as 40 years - in a world in which commercial projects pay back in under ten. Yet the bridge is glorious; symbolic of Denmark's connection to Europe. It is $S$-valuable - if not valuable enough to be justified by $P$, and a flat violation of other-regarding virtues of $O$.

I repeat, it is not merely public projects that bear traces of $O$ and especially $S$ 'irrationality.' Whenever you watch a decision in business, big or small, you will note how important are the egos and biases and hatreds and loves of the decision-makers. Watch a negotiation for a simple house sale and you will see that it depends on dignities and feelings, roles and pretenses, a give-and-take of politeness, veiling of threats, excusing of hardheadedness because, after all, this is Business we are doing. It depends, that is, on the 'faculty of speech' that Adam Smith thought foundational for the economy, though his followers have ignored it. It depends on the invisible tongue as much as on the invisible hand.

That does not mean that Prudence goes out the window. The sociologist Bruce Carruthers (1996, ch. 7) found that in the early 18th century the buying and selling of stock certificates, which conferred the right to vote for the governors of the East India Company, was strongly affected by Whig-Tory affiliations. Politically active Tories traded mostly with fellow Tories, even though the Whigs offered better deals. The great Swedish economist and historian Eli

\footnotetext{
${ }^{5}$ Flyvbjerg et al. (2004, p. 87). But he needs to consider the Winner's Curse.
} 
Heckscher (1934, Vol II, p. 137) paused in his book of 1931 about 17th and 18th century mercantilism to reflect on the mix of $P$ and $O$ and $S$ that rules:

People are actuated, to a greater extent than one tends to admit, by their more or less conscious ... notions of what is right and natural. This does not contradict the view of their being governed by 'self-interest' ... for they partly interpret their own interests in the light of this conception.... They often feel hampered in asserting their interests in such a direction as they themselves consider harmful to the general good.

During the Great Depression, American private investment did not recover until Roosevelt's Dr New Deal gave way to Dr Win-the-War. Part of this was prudence. Unlike Dr Win-the-War, Dr New Deal talked socialism to the economic royalists, the businesspeople whom Roosevelt did not like. A royalist would have been imprudent to invest heavily in a coal mine or auto factory, as Robert Higgs (1997) has noted, if the federal government was likely to expropriate it next year. But part of the refusal to cooperate with the New Deal was $S$-ish animal spirits, too, arrayed viciously against That Man in the White House. A Peter Arno cartoon from the Depression shows a group of idiotically grinning swells in evening dress on the street inviting some others looking out of French windows to 'Come along. We're going down to the TransLux and hiss Roosevelt.'

It is often a scientific mistake, that is, to rely on $P$ alone, and to reject $O$, as is often done by economists, or $S$, as is always done by economists. Or, I say as an economist, vice versa. The economist asks the sociologist how much prudent profit was sacrificed by indulging one's political tastes or being just towards ones brother in law. Since the economist Gary Becker first raised it, the quantitative question has been important in discussions of discrimination by race or gender. But turn-about is fair play. How much does $P$ matter by itself? For some cases, admittedly, $P$ is overwhelmingly important. If you are trying to explain covered interest arbitrage in the foreign exchanges I advise you to forget about $O$ and $S$, pretty much. Love and faith are not going to explain the picking up of a profit of $\$ 400$ million in the portfolio of the Chase Manhattan. Prudence will. On the other hand, if you are trying to explain voting or ethics or marriage or church attendance you will fall into what Michael Polanyi (1958, p. 88), in a similar connection, once called 'voluntary imbecility', if you simply ignore $O$ and $S$ and their interesting interactions with $P$.

In 1952, a woman who wanted a divorce was wrong-footed from the start, although entitled to alimony if she could catch him in a hotel with his mistress. No longer. $O$ and $S$ have changed, and the changes have had financial implications: what is thought of as just affects how courts judge divorce cases and the faithful identity of women as mothers has been redefined. It is not merely that some curve has shifted, as the economists want to put it, since then they can go on ignoring $O$ and $S$. No-fault divorce interacted very strangely with the market, and ended up hurting a good many women. Or maybe not so strangely, a feminist might say.

Most economics and most anthropology/sociology is persuasion about the quantitative mixture of prudence on the one hand and an other-regarding and value-regarding sacred on the other. The question is what matters for any particular case, and about how exactly they interact. The right-wing evolutionists of the 1970s, especially E. O. Wilson, were enthusiastically received by economists like 
Becker. Left-wing evolutionists, especially S.H. Gould and Richard Lewontin, were enthusiastically received by the Union of Radical Political Economists. The debate was at the political level a matter of $P$ versus $O$ and $S$. (At the scientific level it is perhaps better described as $P$ versus $P+\epsilon$, the (large) error term $\epsilon$ reflecting nonprudent evolutions of spandrels and five fingers merely stumbled into. But we're talking about crude intellectual politics here.) The non-economists see the world as $O$ and $S$, largely. The economists want the world to be $P$ only. The world isn't buying.

\section{Against $P$-Only Reductions}

$P$-only is not of course confined to economists. A group of game-theory inspired biologists and psychologists have also been trying now for a few decades to sell $P$-only. The current debate between evolutionary psychologists such as Steven Pinker of Harvard and a group of sophisticated doubters such as Noam Chomsky and Jerry Fodor is a case in point. Are we nice to each other because of some hidden, and scientifically undocumented, long-run prudence of evolution which hard-wires particular moral precepts? Or are we nice because we subscribe to the sacred ethical texts of our culture written on a practically blank slate?

As H. Allen Orr (2003) observes, Pinker (a $P$ man) defends evolutionary psychology, which reinvented Schopenhauer, even when it leads to ethically unhelpful theories - for example, 'Men rape to spread their seed' - by huffing that after all we still have other-regarding and a transcendent sacred to oppose such barbarities. Presumably Pinker would give the same answer to complaints about the homophobic theories put forward by some of his very good friends. $S$ rescues us, Pinker suggests, from the nastiness of pure $P$. Pinker's program will therefore not, he seems to promise, degenerate into a revival of the German Empire's Paragraph 175 for homosexuals, programs of eugenics for all, and the forced sterilization of the inferior types.

'Pinker barely notices,' writes Orr (2003, p. 18), 'that the morality that's always there to save the day ... is itself a legacy of the despised Blank Slate of Lockean liberalism.' Darwinian $P$ may 'may well have endowed us with a crude morality, but this can't explain why kings but not women once had rights, but now women but not kings do.' Or as the late Richard Rorty (2004, p. 21) asked about Pinker's ruminations, 'How will this ability [to "explain" behavior in evolutionary terms] help us figure out what sort of behavior to encourage?' Rorty argued that we get our notions of good behavior from philosophers and, especially, novelists, and that the attempt by Pinker and others to substitute Science for Value by treating 'platitudes as gee-whiz scientific discoveries' is a category mistake. What is true about the fact-value split is that What Is cannot simply be taken as being just the same thing as What Should Be. We can't naturalize ethics that much.

The moral slate seems in fact to be practically empty of particular precepts. To buttress his theory that we are mostly not anti-social precisely because we are hard-wired to be nice, Pinker is fond of instancing adult sociopaths, who supposedly are missing some wiring. It may be so. Yet one wonders if Pinker has ever known a two-year old, or for that matter a 15-year old; or if he has noted the variation country-to-country in niceness. Every human is born in sin, we Christians think, and must seek redemption. Or in a secular formulation, 
ordinary Germans can with relative ease, if prepared by decades of anti-Semitic politics, be turned into mass murderers.

It would seem that the superstructure of ethical or aesthetic or social behavior is not determined in much detail by genes. As the biologist Peter Medawar, discussing an earlier outbreak of the nature/nurture controversy, expressed it, 'Human beings owe their biological supremacy to a form of inheritance quite unlike that of other animals: exogenetic or exosomatic heredity,' namely, culture (quoted in Hearnshaw, 1979, p. 137).

Ethics is like language, whose deep grammar may be hard wired but whose glorious detail is in its software applications. Of course, the answer to the nature/ nurture/choice debate depends in detail on what you mean by detail. If you want to explain the difference between the music of humans and the music of dolphins, genes are a good place to look - although pack-by-pack the dolphins, by the way, seem to have musical, or maybe linguistic, cultures, too (MacIntyre, 1999, ch. 3). A female elephant raised close to a highway developed a growl that sounded like the trucks, her herd (Poole et al., 2005). But if you want to explain the difference between Mozart and rap music, then culture, tradition, irony, choice, politics, the creativity of that exogenetic or exosomatic heredity are better places to look. As Louis Menand (2002) observed of Pinker's claims, 'Music appreciation ... seems to be wired in at about the level of "Hot Cross Buns." But people learn to enjoy Wagner. They even learn to sing Wagner. One suspects that enjoying Wagner, singing Wagner, anything to do with Wagner, is in gross excess of the requirements of natural selection.'

The evolutionary sociologist Jonathan Turner (2000) has argued that what did evolve biologically was a hard-wired propensity for morality, with not much of its specific content. He speculates that the move to the savannah by early hominids required more connection within the group than was necessary in the more secluded environs of the trees. 'Selection worked to give [the new] hominids the ability to use emotions [such as love of solidarity or fear of social sanctions] to build flexible systems of moral codes,' (Turner, 2000, p. 54) adjustable to groups wandering the savannah in search of grubs and game.

It may be. Millions of years of selection back in the trees for 'autonomy, weak tie-formation, and fluid social relations' among our proto-great-ape ancestors had to be offset, Turner believes, and in a hurry. A proto-great-ape venturing into the savannah who went on doing his own thing in lofty disdain of morality would get eaten by proto-lions. The new 'neurological capacity to construct moral codes,' with intensifiers such as ritual and language and labile emotions to go along with them, did the trick, economically (Turner, 2000, p. 52).

It's not all good news, this flexible ability to construct moral codes. As the economist Paul Seabright (2004, p. 7) notes, 'like chimpanzees, though with more deadly refinement, human beings are distinguished by their ability to harness the virtues of altruism and solidarity, and the skills of rational reflection, to the end of making brutal and efficient warfare.' Thus, the First Crusade was inspired by theories of just war, as nowadays the anti-crusade of Moslem martyrs is inspired by parallel theories. But anyway, Turner's story seems rather more plausible than Pinker's, and by the way reads less like a politicallypointed just-so story helpful to the radical wing of the Republican Party. 
Still, one tires of the boyish enthusiasm in philosophy, psychology, economics, sociology, and the fourth estate for neo-evolutionary and gametheoretic arguments. The boys do not realize that the Folk Theorem spoils the game. Perhaps the limitless number of solutions implied by the theorem accounts for the limitless parade of pseudo-explanations. As some wise heads put it, 'The prediction that individuals might do anything from a large set of feasible strategies is neither useful nor precise' (Ostrom et al., 1994, p. 322).

It would be nice to see some actual evidence. The evidence from brain science is that so far we know practically nothing about the connection between brains and minds. This doesn't leave much room for confident statements similar to those about the effects of island size on animal size or of sunshine on inherited human skin color. The mind-brain connections we know about are too loose to help much in explaining ethics. As Jerry Fodor (1998, p. 2) says,

Unlike our minds [and our postures and hair distributions, say], our brains are, by any gross measure, very like those of apes. So it looks as though relatively small alterations of brain structure must have produced very large behavioral discontinuities in the transition from the ancestral apes to us. If that's right, then you don't have to assume that cognitive complexity is shaped by the gradual action of Darwinian selection on pre-human behavioral phenotypes.

Fodor is vexed at people like Pinker who claim credit on some future, 23rd-century brain science today. He counsels humility: 'I'd settle for the merest glimpse of what is going on.'

\section{Boyish $P$-Only}

So-called 'welfare economics' has recently shown some faint stirrings of complexity in ethical thought, as in the works of younger economists and philosophers inspired by Sen's forays. Sen complained of the 'lack of interest that welfare economics has had in any kind of complex ethical theory,' such as his agency/commitment idea, or the still more rich ethical theory that could be found in philosophy and fiction from the Rig Vida to the present. Sen (1987, p. 50) added: 'It is arguable that [utilitarianism and] ... Pareto efficiency have appealed particularly because they have not especially taxed the ethical imagination of the conventional economist.' Truth be known, this 'welfare economics' and what passes for 'ethical' theorizing among economists and economics-loving philosophers is a Victorian, utilitarian parrot, stuffed and mounted and fitted with marble eyes, a Norwegian blue 'pining for the fjords.' Time to take the stuffed parrot back to the pet store.

Sen argued that important realms of our lives are governed instead by a commitment that reduces your utility, at any rate your first-order utility in the manner of ice cream eaten or son's-college-degree attained. In Kantian terms, commitment is a duty. In virtue-ethical terms, commitment is a matter of justice, faith, and transcendent love, a mix of $O$ and $S$ variables. Not prudence only. Commitment involves 'counterpreferential choice, destroying the crucial assumption [of Max-U, that Samuelsonian, economics] that a chosen alternative must be better 
than ... the others for the person choosing it' (Sen, 1987, p. 50). Acknowledgement of the virtues beyond prudence and passion, in short, 'drives a wedge between personal choice and personal welfare.' 'Much of traditional economic theory relies on the identity of the two' (Sen, 1977, p. 329). In doing so, economics assumes a world without ethical commitment: 'The purely economic man is indeed close to being a social moron' (Sen, 1977, p. 336). Come to think of it, no 'close' about it.

Samuelsonian economists want to explain everything - simply everything from medieval open fields to the productivity of British steel making before 1914, with the simplest possible, boy's-own version of $P$ only. Without being explicit enough, though, some economists, and some of the best, do acknowledge $O$ and $S$ variables. Theodore Schultz (1964) argued that peasants in poor countries were prudent and that it was a mistake to explain their behavior anthropologically; as a dogmatic anthropologist might say: 'behavior equals some constant plus the effect of the sacred, plus an error term for human variability, $B=\alpha+\gamma S+\varepsilon$, with the $S$ variable alone.' Schultz said: Even these 'traditional' peasants care about $P$, too. Add it to the equation. But Schultz did not ignore the $O$ and $S$ variables. The education of women, he argued forcefully, was crucial in making prudence work, and the education would depend on other-regarding concern for the women and on overcoming sacred patriarchal objections to their literacy. He got the evidence.

Many economists go through a Bildung of this sort, starting in graduate school as $P$-only folk and coming by age 50 or so to realize that people are in fact motivated by more than prudence. I did. Robert Fogel started in his youth, like me, as a $P$-only Marxist and became, like me, a $P$-only economist and then discovered, like me, the force of religion in economic behavior. Even Gary Becker shows signs of such a development, in seeing that commitment or ethics or bourgeois virtues are fulfillments, not betrayals, of the science of economics. We should encourage them, out of other-regarding love and a sacred commitment to a science of economics. The long experiment in $P$-only economics has produced a lot of good science. But there's a great deal more to be had by building into our thinking the virtues of $O$ and $S$.

\section{References}

Carruthers, B. (1996) City of Capital: Politics and Markets in the English Financial Revolution (Princeton: Princeton University Press).

Charry, E. (2004) On happiness, Anglican Theological Review, 86, pp. 19-33.

Dougherty, P. (2002) Who's Afraid of Adam Smith: How the Market Got Its Soul (New York: Wiley).

Eliade, M. (1959) [1957] The Sacred and the Profane: The Nature of Religion (New York: Harcourt, Brace \& World).

Flyvbjerg, B., Holm, M.K.S. \& Buhl, S. (2003) How common and how large are cost overruns in transport infrastructure projects?, Transport Reviews, 23, pp. 71-88.

Flyvbjerg, B. (2004) Megaprojects: misrepresentation drives projects, Engineering News Record, 5 January, p. 87. Available at http://www.plan.aau.dk.

Fodor, J. (1998) The trouble with psychological Darwinism, London Review of Books, 20(2), 15 January.

Folbre, N. (2001) The Invisible Heart: Economics and Family Values (New York: The New Press).

Foot, P. (2001) Natural Goodness (Oxford: Clarendon Press). 
Frank, R. (1988) Passions within Reason: The Strategic Role of the Emotions (New York: W.W. Norton).

Hearnshaw, L.S. (1979) Cyril Burt: Psychologist (Ithaca: Cornell University Press).

Heckscher, E. (1931) Mercantilism (London: Allen \& Unwin, 1934).

Higgs, R. (1997) Regime uncertainty: why the Great Depression lasted so long and why prosperity resumed after the war, Independent Review, 1, pp. 561-590.

Horowitz, D. (1985) The Morality of Spending: Attitudes toward the Consumer Society in America, 1875-1940 (Baltimore: Johns Hopkins University Press).

Hunt, L. (1997) Character and Culture (Lanham, MD: Rowman \& Littlefield).

Jackson, J. (1996) An Introduction to Business Ethics (Oxford: Blackwell).

Jones, E. (2006) Cultures Merging: A Historical and Economic Critique of Culture (Princeton: Princeton University Press).

Lynn, M. \& Lynn, A. (2004) National values and tipping customs: a replication and extension, Journal of Hospitality and Tourist Research, 28, pp. 356-364.

MacIntyre, A. (1999) Dependent Rational Animals. Why Human Being Need the Virtues (Chicago and LaSalle, Illinois: Open Court).

McCloskey, D. (2004) What would Jesus spend? Why being a good Christian won't hurt the economy, The Christian Century, May 4, pp. 24-30.

McCloskey, D. (2006) The Bourgeois Virtues: Economics for an Age of Commerce (Chicago: University of Chicago Press).

Menand, L. (2002) What comes naturally: does evolution explain who we are?, The New Yorker, November 25, p. 96.

Novak, M. (1996) Business as a Calling: Work and the Examined Life (New York: Free Press).

Orr, H.A. (2003) Darwinian storytelling, New York Review of Books, February 27, pp. 17-20.

Ostrom, E., Gardner, R. \& Walker, J. (1994) Rules, Games, and Common-Pool Resources (Ann Arbor: University of Michigan Press).

Polanyi, M. (1958) Personal Knowledge: Towards a Post-Critical Philosophy (Chicago: University of Chicago Press).

Poole, J. H., Tyack, P.L., Stoeger-Horwathm, A.S. and Watwood, S. (2005) Animal behaviour: elephants are capable of vocal learning, Nature, 434, pp. 455-456.

Renan, E. (1863) Vie de Jésus

Rorty, R. (2004) Philosophy envy, Daedalus, 133, pp. 18-24.

Schultz, T. (1964) Transforming Traditional Agriculture (New Haven: Yale University Press).

Seabright, P. (2004) The Company of Strangers: A Natural History of Economic Life (Princeton: Princeton University Press).

Sen, A. (1977) Rational fools: a critique of the behavioral foundations of economic theory, Philosophy and Public Affairs, 6, pp. 317-344.

Sen, A. (1987) On Ethics and Economics (Oxford: Blackwell).

Sen, A. (2000) Development as Freedom (New York: Knopf).

Turner, J. (2000) On the Origins of Human Emotions (Princeton: Princeton University Press).

Ulrich, L. (1990) A Midwife's Tale: The Life of Martha Ballard, Based on Her Diary, 1785-1812 (New York: Random House).

Van Staveren, I. (1999) Caring for Economics: An Aristotelian Perspective (Delft: Eburon Academische Uitverij).

Van Staveren, I. (2001) The Values of Economics: An Aristotelian Perspective (London \& New York: Routledge).

Weber, M. [1905] (1958) The Protestant Ethic and the Spirit of Capitalism (New York: Scribner's).

Wolf, S. [1982] (1997) Moral Saints, in: R. Crisp \& M. Slote € Eds) Virtue Ethics (Cambridge: Cambridge University Press), pp. 79-98. 
Copyright of Review of Political Economy is the property of Routledge and its content may not be copied or emailed to multiple sites or posted to a listserv without the copyright holder's express written permission. However, users may print, download, or email articles for individual use. 